\title{
Meriç Nehri Havzasında Sıcaklık ve Yağış Değerlerinin Dönemsel Trend Analizi
}

\author{
İlker Eroğlu ${ }^{*}$ \\ 1* Tekirdağ Namık Kemal Üniversitesi, Fen Edebiyat Fakültesi, Coğrafya Bölümü, Tekirdağ, Türkiye, (ORCID: https://orcid.org/0000-0003-4601-024X), \\ ieroglu@nku.edu.tr
}

(İlk Geliş Tarihi 18 Şubat 2021 ve Kabul Tarihi 20 Nisan 2021)

(DOI: $10.31590 /$ ejosat.882937)

ATIF/REFERENCE: Eroğlu, İ. (2021). Meriç Nehri Havzasında Sıcaklık ve Yağış Değerlerinin Dönemsel Trend Analizi. Avrupa Bilim ve Teknoloji Dergisi, (23), 750-760.

\begin{abstract}
$\ddot{O} \mathbf{z}$
Bu çalışmada Türkiye'nin en önemli sınır oluşturan ve sınır aşan akarsularından biri olan Meriç Nehri Havzası'nın yıllık ortalama sıcaklık ve yă̆ı̧̧ değerlerinin dönemlik trend analizinin yapılması amaçlanmıştır. Bulgaristan ve Türkiye sınırları içinde kalan 10 meteoroloji istasyonunun yaklaşık 50 yıllık verilerinin dönemsel (1965-1990, 1991-2015 ve 1965-2015) yillık ortalama sicaklık ve yağış verilerinin pozitif ya da negatif yönlü eğilimleri belirlenmiştir. Bu veriler ışığında küresel iklim değişikliğinin ve küresel ısınmanın havza alanının yıllık sıcaklık ve yağış ortalamalarına etkileri istatistiksel olarak ortaya konulmaya çalışılmıştır. Çalışmada yöntem olarak parametrik olmayan testlerden Mann-Kendall Testi ve Sen'in Trend Eğim testi kullanılmış̧ır. Ortaya çıkan trend analizleri sonuçlarına göre yıllık ortalama sıcaklıklar 1965-1990 yılları arasını kapsayan dönemde sadece Lüleburgaz istasyonunda anlamlı negatif bir trend, 1991-2015 döneminde Lüleburgaz dışında istasyonların hepsinde anlamlı pozitif trend ve 1965-2015 döneminde Kazanlak, Sliven, Pazardzhik, Haskovo, Kırklareli, Edirne, Lüleburgaz, Çorlu, Tekirdağ ve İpsala'da anlamlı ve pozitif yönlü trend göstermektedir. Yıllık yağış ortalamalarında 1965-1990 döneminde Kazanlak, Sliven, Pazardzhik, Haskovo ve İpsala'da anlamlı negatif yönlü trend ve 1991-2015 döneminde genel eğilim artış yönünde olmakla birlikte Kırklareli istasyonunda anlamlı pozitif yönlü bir trend vardır. 19652015 döneminde havza alanındaki hiçbir istasyonda istatistiksel olarak anlamlı bir trend bulunmamaktadır. Meriç Nehri Havzası'nın yıllık ortalama sıcaklık ve yağış trendlerindeki değişmeler beraberinde su kıtlığı veya taşkın riskinin artması, kuraklık, toprak erozyonu, arazi degradasyonu, ekolojik dengede bozulmalar, tarımsal verimin düşmesi, büyükbaş ve küçükbaş hayvancılık faaliyetlerinin olumsuz etkilenmesi gibi pek çok sorunun ortaya çıkmasına neden olacaktır. Bundan dolayı havza alanı ile ilgili planlamalarda ve sorunların çözümünde ortalama sıcaklık ve yağış trendlerindeki değişiklikler göz önünde bulundurulmalıdır.
\end{abstract}

Anahtar Kelimeler: Meriç Nehri, Mann-Kendall, Trend analizi, Sıcaklık, Yağış, İklim değişikliği.

\section{Periodical Trend Analysis for Temperature and Precipitation in the Maritsa River Basin}

\begin{abstract}
The present study aims to conduct trend analysis on the annual average temperature and precipitation values for the basin of the Maritsa (Meriç) River, one of the most important boundary and transboundary rivers in Turkey. The analysis reveals the positive and negative trends in the annual average temperature and precipitation data on a periodical basis over the course of around 50 years (1965-1990, 1991-2015 and 1965-2015) collected from 10 meteorological stations within the borders of Bulgaria and Turkey. In light of these data, the study attempts to provide a statistical account of the impact of global climate change and global warming on the annual temperature and precipitation averages in the basin. The Mann-Kendall Test and Sen's Trend Slope Test, both of which are non-parametric tests, are used as the methodology of the study. In terms of annual average temperatures, the trend analysis results indicate that only the Lüleburgaz station displays a significant negative trend during the period between 1965 and 1990, that all stations apart from Lüleburgaz display a positive trend during the 1991-2015 period, and that the stations in Kazanlak, Sliven, Pazardzhik, Haskovo, Kirklareli, Edirne, Lüleburgaz, Çorlu, Tekirdağ and İpsala show a significant and positive trend. As far as annual average precipitation values are concerned, while the trend in the Kazanlak, Sliven, Pazardzhik, Haskovo and İpsala stations is significant and negative during the 19651990 period with an overall increasing trend in the 1991-2015 period, the Kirklareli station displays a significant and positive trend. No station in the basin displays statistically significant trends in the 1965-2015 period. The changes in the annual average temperature and
\end{abstract}

*Sorumlu Yazar: ieroglu@nku.edu.tr 
precipitation in the Maritsa River basin bring about a plethora of problems such as the increase in the water shortage and flood risks, drought, soil erosion, land degradation, deteriorations in the ecological balance, decrease in agricultural productivity, and issues in cattle and sheep and goat farming. Therefore, the changes in the average temperature and precipitation trends must be taken into consideration within the plans to be made for the basin area and for the solution of the problems.

Keywords: Maritsa (Meriç) River, Mann-Kendall, Trend analysis, Temperature, Precipitation, Climate change.

\section{Giriş}

Son yıllarda en fazla konuşulan ve tartışılan konuların başında küresel iklim değişikliği ve küresel ısınma gelmektedir. Geçmiş dönemlerde dünya yörüngesindeki değişiklikler, güneş patlamaları, volkanik püskürmeler ve kıtaların kayması gibi doğal etkenlerin neden olduğu iklim değişikliklerine günümüzde antropojenik etkenler sebep olmaktadır. Özellikle sanayi devriminin yaşanması ve hızlı nüfus artışıyla birlikte atmosfere salınan sera gazları miktarlarının artması ve doğal çevre üzerindeki insan tahribatları nedenleriyle atmosferin yeryüzüne yakın bölgeleri gereğinden fazla 1sınmaktadır (Kadığlu, 2019). İklim elemanlarından sıcaklık ve yağış değerlerinin trendlerinde meydana gelen pozitif veya negatif yönlü değişimler küresel iklim değişikliğinin etkilerini anlamada önemli göstergeler olmakla birlikte özellikle 1990 yıllardan sonra bu etkinin çok daha fazla hissedilmeye başladığ görülmektedir. Nitekim 1995-2006 y1lları arası 1850'den beri görülen en sicak dönem olmuştur (Atalay, 2013).

Türkiye'nin sınır aşan akarsularından birini oluşturan Meriç Nehri, sadece Türkiye açısından değil Bulgaristan ve Yunanistan ülkeleri için de tarım alanlarının sulanması, içme ve kullanma suyu temini, elektrik enerjisi üretimi ve hayvancılık için önemli bir kaynaktır.

Genel olarak sulu tarımın yapıldığı Meriç Nehri Havzası, oldukça önemli tarım alanlarını ihtiva etmektedir. Bu verimli tarım alanları aynı zamanda bu yörede yaşayan kırsal nüfus için önemli geçim sahası özelliği taşımaktadır. Tarımsal faaliyetlerin entansif metotlarla yoğun bir şekilde gerçekleştirildiği bu tarım alanlarında tahıllar ve çeltik üretimi ile birlikte çok çeşitli sebze ve meyve yetiştirilmekte, büyük ve küçükbaş hayvancılık, kurbağa avcılığı ve balıkçılık gibi ekonomik faaliyetler önemli geçim kaynakları arasında yer almaktadır (Özşahin vd., 2020; Özşahin ve Eroğlu, 2019).

Meriç Nehri Havzası'nın iklim özelliklerini ortaya koymak amacıyla Bulgaristan sınırları içindeki Kazanlak, Sliven, Pazardzhik ve Haskovo, Türkiye'deki Kırklareli, Edirne, Lüleburgaz, Çorlu, Tekirdağ ve İpsala meteoroloji istasyonlarının aylık ve yıllık ortalama sıcaklık ve yağış verilerine Thornthwaite ve De Martonne yıllık kuraklık indisi formülleri uygulanmıştır.

Thornthwaite iklim sinıflamasına göre Kazanlak ve Pazardzhik $\left(\mathrm{C}_{1} \mathrm{~B}_{1}{ }_{1} \mathrm{~d}_{\mathrm{b}}{ }_{3}\right)$ kurak-az nemli, birinci dereceden mezotermal, su fazlası olmayan veya çok az olan ve denizel şartlara yakın iklim tipine, Sliven $\left(\mathrm{C}_{1} \mathrm{~B}_{3}{ }_{3} \mathrm{~d} \mathrm{~b}_{3}\right)$ kurak-az nemli, üçüncü dereceden mezotermal, su fazlası olmayan veya çok az olan ve denizel şartlara yakın iklim tipine, Haskovo $\left(C_{2} B{ }_{1} s\right.$ b' ${ }_{3}$ ) yar1 nemli, birinci dereceden mezotermal, yaz mevsiminde orta derecede su noksanı olan ve denizel şartlara yakın iklim tipine, Kırklareli, Edirne ve Çorlu ( $\left.\mathrm{C}_{1} \mathrm{~B}_{2}{ }_{2} \mathrm{~s}_{\mathrm{b}}{ }_{3}\right)$ kurak-az nemli, ikinci dereceden mezotermal, kış mevsiminde orta derecede su fazlası olan ve denizel şartlara yakın iklim tipine, Lüleburgaz $\left(\mathrm{C}_{1} \mathrm{~B}^{\prime}{ }_{1} \mathrm{~s}_{2} \mathrm{~b}_{3}{ }^{\prime}\right)$ kurak-az nemli, birinci dereceden mezotermal, kış mevsiminde çok kuvvetli su fazlası olan ve denizel şartlara yakın iklim tipine, Tekirdağ $\left(\mathrm{C}_{1} \mathrm{~B}^{\prime}{ }_{2} \mathrm{~s}_{2} \mathrm{~b}^{\prime}{ }_{3}\right)$ kurak-az nemli, ikinci dereceden mezotermal, kıș mevsiminde çok kuvvetli su fazlası olan ve denizel şartlara yakın iklim tipine ve İpsala $\left(\mathrm{C}_{2}\right.$ $\mathrm{B}_{2} \mathrm{~s}_{2} \mathrm{~b}_{3}{ }_{3}$ ) yarı nemli, ikinci dereceden mezotermal, yaz mevsiminde çok kuvvetli su noksanı olan ve denizel şartlara yakın iklim tipine girmektedir.

De Martonne'nun yıllık kuraklık indisi (1942) formülüne göre (Ardel vd., 1965) Kazanlak nemli (I:24,8), Sliven nemli (I:24,4), Pazardzhik nemli (I:25,6), Haskovo nemli (I:22,0), Kırklareli yarıkurak-nemli (I:16,3), Edirne yarıkurak-nemli (I:17,5), Lüleburgaz yarıkurak-nemli (I:16,3), Çorlu yarıkuraknemli (I:17,0), Tekirdağ yarıkurak-nemli (I:15,7) ve İpsala yarıkurak-nemli (I:15,9) iklim özelliği göstermektedir.

Yukarıdaki değerlendirmelerden Meriç Nehri Havzası'nda Thornthwaite iklim sinıflamasına göre Kazanlak, Pazardzhik, Sliven, Kırklareli, Edirne, Çorlu, Lüleburgaz ve Tekirdağ'da kurak-az nemli, Haskovo ve İpsala'da yarı nemli iklim tipi, De Martonne'nun y1llık kuraklık indisine göre Bulgaristan sınırları içinde kalan Kazanlak, Sliven, Pazardzhik ve Haskovo nemli, daha güney enlemlerde Türkiye sınırları içinde kalan Kırklareli, Edirne, Lüleburgaz, Çorlu, Tekirdağ ve İpsala'da yarı kuraknemli iklim tipi görüldüğü anlaşılmaktadır. Türkeş (2012)'in yaptığı kuraklık indisi çalışmasında, Aşağı Meriç Havzası da dâhil olmak üzere Trakya'nın büyük bölümü yarı nemli indis aralığında kalmakta ve Türkiye'nin klimatolojik olarak yıllık su açığı bulunan, kuraklık ve çölleşmeye eğilimli bölgelerine karş1lık gelmektedir. Bununla birlikte Nojarov (2017), Balkan Yarımadası'nın ikliminin okyanusal ile karasal iklim ve subtropikal ile 1lıman iklimler arasında geçiş özelliği gösterdiğini ve 1950-2012 periyodunda Balkan Yarımadası üzerindeki atmosfer sirkülasyonunda bazı önemli değişiklikler olduğunu belirtmiştir.

Meriç Nehri Havzası ve çevresiyle ilgili daha önce yapılmış olan bazı çalışmalarda sıcaklık ve yağış trendleriyle ilgili şu tespitler bulunmaktadır;

Türkeş (1996), 1930-1993 yılları arasındaki yıllık yağış miktarlarında aralarında Çorlu, Lüleburgaz, Kırklareli, Edirne, ve Tekirdağ'ın da bulunduğu Marmara Bölgesi meteoroloji istasyonlarından sadece Lüleburgaz'da azalma yönünde anlamlı bir trend tespit etmiştir.

Knight ve Staneva (1996), Bulgaristan'da 1961-1994 dönemi yağışlarda artan bir kuraklık eğilimi olduğunu ve bu azalma eğiliminin istatistiksel olarak anlamlı bulunduğunu belirtmiştir.

Kadıŏlu (1997), Türkiye genelinde yıllık ortalama sıcaklık kayıtlarının 1955-1989 yılları arasında soğuma trendi gösterdiğini vurgulamıştır.

Partal (2002), Marmara Bölgesi istasyonlarının (Çorlu, Edirne, Florya, Göztepe, Kırklareli, Kocaeli, Lüleburgaz, Sakarya, Şile ve Tekirdağ) 65 yıllık (1929-1993) yağış serilerinin hiçbirinde \%95 seviyesinde önemli bir trend bulmamıştır.

Türkeş vd. (2007), Türkiye'de yıllık toplam yağışlarda ve yağış yoğunluğu tutarlarında belirgin bir azalma eğilimi olduğunu, yağış yoğunluğu açısından bu azalmanın Marmara 
Bölgesi istasyonlarında daha kuvvetli olduğunu tespit etmişlerdir.

Ölgen (2010), yağış değişkenliği katsayısının Marmara Geçiş Yağış Rejim Bölgesi'ndeki hemen hemen tüm istasyonlarda \%25 sınır değerinin altında (\%17-21 arası) kaldığını belirtmiştir.

Gönençgil (2012), Trakya'da 1975-2011 yılları arası ortalama sıcaklıklarda artış yönünde anlamlı trendler tespit etmiştir. Yıllık yağış serilerinde Kırklareli'nde 1989-1997, Tekirdağ'da 1992-1993 döneminde, Çorlu'da 1989-1990 ve 1992-1994 döneminde önemli kurak koşulların görüldüğünü belirlemiştir. Toplam yıllık yağışlarda Edirne ve Kireçburnu haricinde bütün istasyonlarda azalma trendi görülmüş, Edirne'de 1975'ten beri gözlenen azalma trendi, 1990'ların başından itibaren artma trendine girmiştir.

Turoğlu ve Uludağ (2013), Meriç Nehri Havzası'nın Türkiye'deki bölümünde taşkın ve su yetersizliği sorunları, su kalitesinin kötüleşmesi, ekosistem problemleri ve yerel halkın sosyo-ekonomik sorunları gibi problemlerin giderek arttığını vurgulamıştır.

Meteoroloji Genel Müdürlüğü (2014), Ergene Havzası'nda RCP4.5 ve RCP8.5 senaryolarına göre ortalama sıcaklık (20132040, 2041-2070, 2071-2099) ve yağışlarda (2011-2040, 20412070, 2071-2099) bütün dönemlerde artış eğilimi olduğunu tespit etmiştir.

Hanedar vd. (2019), MPIESM-MR modeli, RCP4.5 ve RCP8.5 senaryosuna göre 2015-2100 projeksiyon süresince yıllık ortalama sıcaklık değerlerinin $3^{\circ} \mathrm{C}-3,9^{\circ} \mathrm{C}$ artacağı ve en yüksek sıcaklık artışlarının Edirne'de gerçekleşeceği tespit etmiştir. HadGEM2-ES modeli RCP4.5 ve RCP8.5 senaryo sonuçlarına göre ise 2015-2100 projeksiyon yılları arasında toplam yağışlarda düzenli bir artıştan veya azalıştan söz etmenin mümkün olmadığını, RCP4.5 senaryosu için yağış artışlarının en fazla Tekirdağ'da beklendiğini, RCP8.5 senaryosu için en fazla yağış azalmasının Edirne için öngörüldüğünü belirlemişlerdir.

Erkal ve Topgül (2020), Mann-Kendall ve Sen'in Trend Eğimi yöntemine göre Aşağı Meriç Nehri akımlarının (19862016) akım trendlerinde ve trendlerin lineer eğilimlerinde artan yönde pozitif trendler ve yıllar içerisinde yukarı yönlü eğilim olduğu tespit etmiştir.
Sıcaklık ve yağış ortalamalarındaki trend analizleri ile ilgili yapılmış çalışmalardan bazıları Demir vd., 2008; Karabulut ve Cosun, 2009; Bayer Altın ve Barak, 2012; Sütgibi, 2015; Kizılelma, vd., 2015; Roboaa ve Al-Barazanji, 2015; Polat ve Sunkar, 2017; Şenocak ve Emek, 2019 ve Coşkun, 2020a dır.

\section{Materyal ve Metot}

Bu çalışmada Meriç Havzası sınırları dâhilinde bulunan Kazanlak, Sliven, Pazardzhik, Haskovo, Çorlu, Edirne, İpsala, Kırklareli, Lüleburgaz ve Tekirdağ meteoroloji istasyonlarının uzun yıllık verileri kullanılmıştır (Tablo 1). Kırklareli, Edirne, Lüleburgaz, Çorlu, Tekirdağ ve İpsala meteoroloji istasyonlarının yıllık ortalama sıcaklık ve yağış verileri (19652015) Meteoroloji Genel Müdürlüğü’nden, Bulgaristan sınırları içinde kalan Kazanlık, Sliven, Pazardzhik ve Haskovo, meteoroloji istasyonlarına ait sıcaklık (1965-2015) ve yağış (1965-2012) verileri kişisel temaslarla Sliven Institut Meteorologiyal Hidrologiya'dan temin edilmiştir.

İklim değişikliğine etki eden parametrelerin analizinde son yıllarda parametrik olmayan testler tercih edilmektedir (Büyükyıldız ve Berktay, 2004). Parametrik olmayan testler veri hatalarından ve eksik değerlerden etkilenmediğinden ve ihtiyaç duyduğu varsayımlar az olduğundan sıcaklık ve yağış verilerinin trend analizi sonuçlarında daha güvenilir sonuçlar vermektedir (Yu vd., 1993; Partal, 2002). Zira sıcaklık ve yağış verilerinin analizinin güvenirliliği elde edilecek bulgular açısından oldukça önemli kabul edilmektedir (Kadıŏlu, 1997; Partal ve Kahya, 2006; Çeribaşı ve Doğan, 2015; Çoşkun, 2020b; Çoşkun, 2020c).

Meriç Nehri Havzası'ndaki meteoroloji istasyonlarının yıllık ortalama sıcaklık ve yağış değerlerindeki trend analizinin tespitinde diğer testlere göre daha güçlü olduğu kabul edilen (Çeribaş1 ve Doğan, 2015) Mann-Kendall testi ve Sen'in Trend Eğim testi tercih edilmiştir (Büyükyıldız ve Berktay, 2004; Gocic ve Slavisa, 2013).

Test değerlerinin pozitif olması artan yönde, negatif olmas azalan yönde bir trend olduğunu ortaya koymaktadır. Bu testlerin uygulanmasında XLSTAT (2020) programının 14 günlük deneme sürümünden yararlanılmıştır (Çalışkan, 2016). Haritaların hazırlanmasında Coğrafi Bilgi Sistemlerinden (CBS) ArcGIS 10.8 programı kullanılmıştır.

Tablo 1. Çalışmada Verileri Kullanılan Meteoroloji Ístasyonları ve Özellikleri.

\begin{tabular}{llllccc}
\hline $\begin{array}{c}\text { İstasyon } \\
\text { Adı }\end{array}$ & $\begin{array}{c}\text { Bulunduğu } \\
\text { Ülke }\end{array}$ & Enlem & Boylam & $\begin{array}{c}\text { Yükselti } \\
(\mathbf{m})\end{array}$ & $\begin{array}{c}\text { Yıllık } \\
\text { Ortalama } \\
\text { Sıcaklık Rasat } \\
\text { Yılları }\end{array}$ & $\begin{array}{c}\text { Yıllık } \\
\text { Ortalama } \\
\text { Yağış Rasat } \\
\text { Yılları }\end{array}$ \\
\hline Kazanlak & Bulgaristan & $42^{\circ} 36^{\prime} \mathrm{K}$ & $25^{\circ} 28^{\prime} \mathrm{D}$ & 366 & $1965-2015$ & $1965-2012$ \\
Sliven & Bulgaristan & $42^{\circ} 42^{\prime} \mathrm{K}$ & $26^{\circ} 19^{\prime} \mathrm{D}$ & 264 & $1965-2015$ & $1965-2012$ \\
Pazardzhik & Bulgaristan & $42^{\circ} 11^{\prime} \mathrm{K}$ & $24^{\circ} 20^{\prime} \mathrm{D}$ & 213 & $1965-2015$ & $1965-2012$ \\
Haskovo & Bulgaristan & $41^{\circ} 55^{\prime} \mathrm{K}$ & $25^{\circ} 36^{\prime} \mathrm{D}$ & 195 & $1965-2015$ & $1965-2012$ \\
Kirklareli & Türkiye & $41^{\circ} 44^{\prime} \mathrm{K}$ & $27^{\circ} 13^{\prime} \mathrm{D}$ & 232 & $1965-2015$ & $1965-2015$ \\
Edirne & Türkiye & $41^{\circ} 40^{\prime} \mathrm{K}$ & $26^{\circ} 33^{\prime} \mathrm{D}$ & 51 & $1965-2015$ & $1965-2015$ \\
Lüleburgaz & Türkiye & $41^{\circ} 23^{\prime} \mathrm{K}$ & $27^{\circ} 20^{\prime} \mathrm{D}$ & 46 & $1965-2015$ & $1965-2015$ \\
Çorlu & Türkiye & $41^{\circ} 07^{\prime} \mathrm{K}$ & $27^{\circ} 54^{\prime} \mathrm{D}$ & 183 & $1965-2015$ & $1965-2015$ \\
Tekirdağ & Türkiye & $40^{\circ} 57^{\prime} \mathrm{K}$ & $27^{\circ} 29^{\prime} \mathrm{D}$ & 4 & $1965-2015$ & $1965-2015$ \\
İpsala & Türkiye & $40^{\circ} 55^{\prime} \mathrm{K}$ & $26^{\circ} 22^{\prime} \mathrm{D}$ & 10 & $1965-2015$ & $1965-2015$ \\
\hline
\end{tabular}




\section{3. Çalışma Alanı}

Çalışma alanını Türkiye, Bulgaristan ve Yunanistan için önemli akarsulardan biri olan Meriç Nehri Havzası oluşturmaktadır (Şekil 1). Kaynağını Bulgaristan'daki Rodop Dağları sırasının kuzey-batı kesimindeki Rila Dağları'nın (2925 m) kuzey yamaçlarından alan Meriç Nehri, Rodop Dağları ile Balkan Dağları arasında tektonik kökenli çukurluğu izleyen batıdoğu doğrultulu bir vadide akarak Dimotrovgrad'dan geçtikten sonra kuzeyden gelen Sazlık kolunu alır ve daha sonra güneydoğuya doğru akar. Bulgaristan'dan çıktıktan sonra $15 \mathrm{~km}$ boyunca Türkiye-Yunanistan sınırını çizer, daha sonra $13 \mathrm{~km}$ Türkiye sınırları içinde akar ve yeniden Türkiye-Yunanistan sınırını oluşturarak Ege Denizi'ne dökülür. Meriç Nehri'nin uzunluğu Bulgaristan sınırları içinde $320 \mathrm{~km}$, havza tamamında 490 km dir (Yıldız, 2011; Erkal ve Topgül, 2015).

Meriç Nehri'ne Edirne'nin batısından sağ kol olarak Arda Nehri, sol kol olarak Tunca Nehri, Dimetoka'nın güneyinden sağ taraftan Kızılçay ve İpsala'nın kuzeyinde sol taraftan Ergene Nehri bağlanır. Meriç Nehri’nin üç ülkenin sınırları içinde yayılan toplam havza alanı $52600 \mathrm{~km}^{2}$ dir. Havza alanının \%65'i (34 067 $\mathrm{km}^{2}$ ) Bulgaristan, \%28'i (14850 km²) Türkiye ve \%7'si (3685 $\mathrm{km}^{2}$ ) Yunanistan sınırları içinde kalmaktadır (Yıldız, 2011; Turoğlu ve Uludağ, 2013).

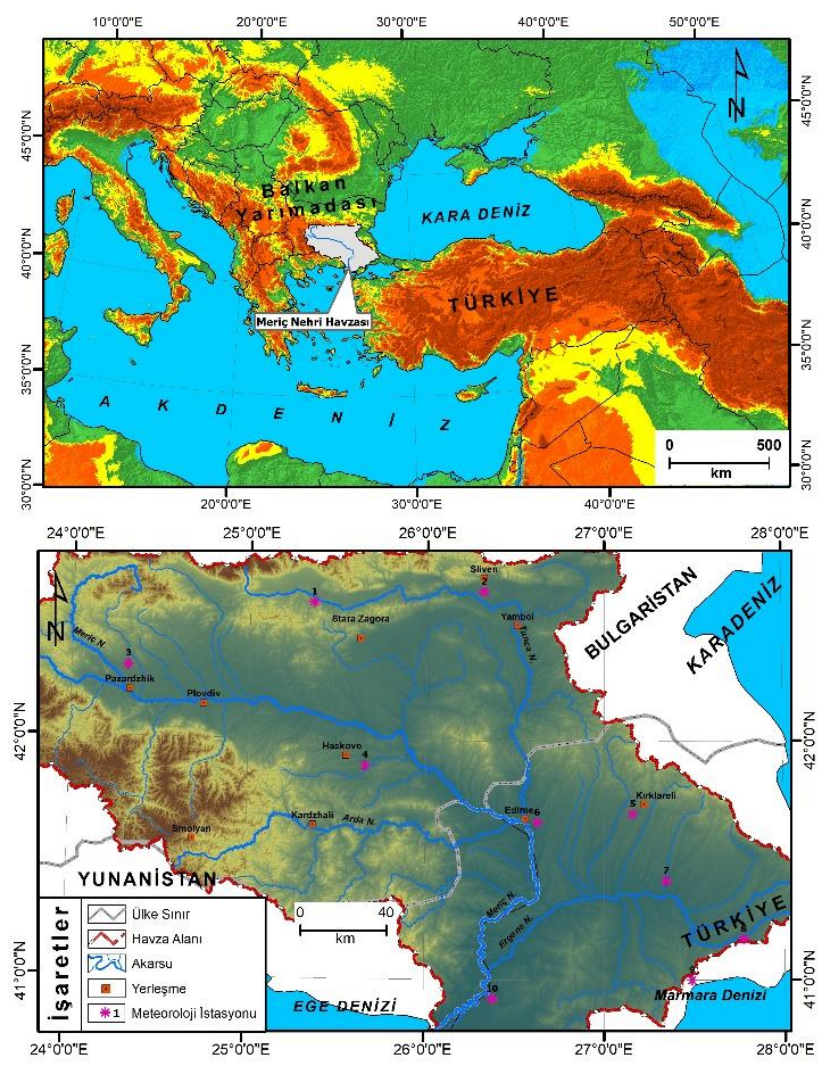

Şekil 1. Meriç Nehri Havzası'nın Lokasyon Haritası.

\section{Araştırma Sonuçları ve Tartışma}

\subsection{Meriç Nehri Havzası'nda 1965-1990 Dönemi Sıcaklık ve Yağış Trend Analizi}

Yıllık ortalama sıcaklıklar 1965-1990 yılları arasını kapsayan dönemde Sliven, Kırklareli, Edirne, Lüleburgaz, Çorlu, Tekirdağ ve İpsala'da azalma trendindedir (Tablo 2, Tablo 3, Şekil 2, Şekil 4). Ancak sadece Lüleburgaz istasyonunda istatistiksel olarak $\alpha=0,05$ anlamlılık seviyesine göre negatif bir trend görülmektedir. Sliven, Kurklareli, Edirne, Çorlu, Tekirdağ ve İpsala'da negatif yönlü eğilim anlamsız bulunmuştur. Bulgaristan'ın Kazanlak, Pazardzhik ve Haskovo istasyonlarında pozitif yönlü bir trend olmasına rağmen istatistiksel olarak yine anlamsız bir özellik göstermektedir.

Mann-Kendall ve Sen'in trend eğimi test analizlerinden elde edilen sonuçların grafiksel olarak gösterimi olan Şekil 2 incelendiğinde de bu değerlerdeki artış veya azalış yönlerinin Tablo 2 ve Tablo 3 'te verilen eğilim çizgisi yönleri ile örtüştüğü anlaşılmaktadır.

Tablo 2. Meriç Nehri Havzası'nda 1965-1990 Dönemi Sıcaklık Trend Değerleri.

\begin{tabular}{|l|c|c|c|}
\hline $\begin{array}{c}\text { İstasyon } \\
\text { Adı }\end{array}$ & $\begin{array}{c}\mathbf{P} \text { (Value) } \\
(\boldsymbol{\alpha}=\mathbf{0 , 0 5})\end{array}$ & $\begin{array}{c}\text { Kendall's } \\
\text { tau }\end{array}$ & $\begin{array}{c}\text { Sen Trend } \\
\text { Eğimi }\end{array}$ \\
\hline Kazanlak & 0,261 & 0,160 & 0,015 \\
\hline Sliven & 0,774 & $-0,043$ & $-0,002$ \\
\hline Pazardzhik & 0,641 & 0,089 & 0,011 \\
\hline Haskovo & 0,454 & 0,108 & 0,006 \\
\hline Kirklareli & 0,612 & $-0,074$ & $-0,005$ \\
\hline Edirne & 0,158 & $-0,200$ & $-0,016$ \\
\hline Lüleburgaz & $\mathbf{0 , 0 0 8}$ & $-0,372$ & $-0,034$ \\
\hline Çorlu & 0,791 & $-0,040$ & $-0,003$ \\
\hline Tekirdağ & 0,252 & $-0,163$ & $-0,009$ \\
\hline İpsala & 0,965 & $-0,009$ & $-0,001$ \\
\hline
\end{tabular}

Tablo 3. Meriç Nehri Havzası'nda 1965-1990 Dönemi Sıcaklık Eğilimleri.

\begin{tabular}{|c|c|c|c|}
\hline $\begin{array}{c}\text { İstasyon } \\
\text { Adı }\end{array}$ & $\begin{array}{c}\text { P (Value) } \\
(\alpha=0,05)\end{array}$ & $\begin{array}{c}\text { Kendall's } \\
\text { tau }\end{array}$ & $\begin{array}{c}\text { Sen Trend } \\
\text { Eğimi }\end{array}$ \\
\hline Kazanlak & & & \\
\hline Sliven & & 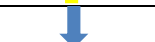 & 6 \\
\hline Pazardzhik & & & \\
\hline Haskovo & & & \\
\hline Kurklareli & & L & 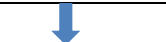 \\
\hline Edirne & & 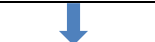 & 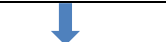 \\
\hline Lüleburgaz & & 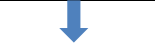 & 1 \\
\hline Çorlu & & 1 & 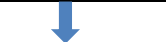 \\
\hline Tekirdağ & & 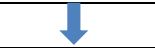 & 1 \\
\hline İpsala & & & $\pi$ \\
\hline
\end{tabular}




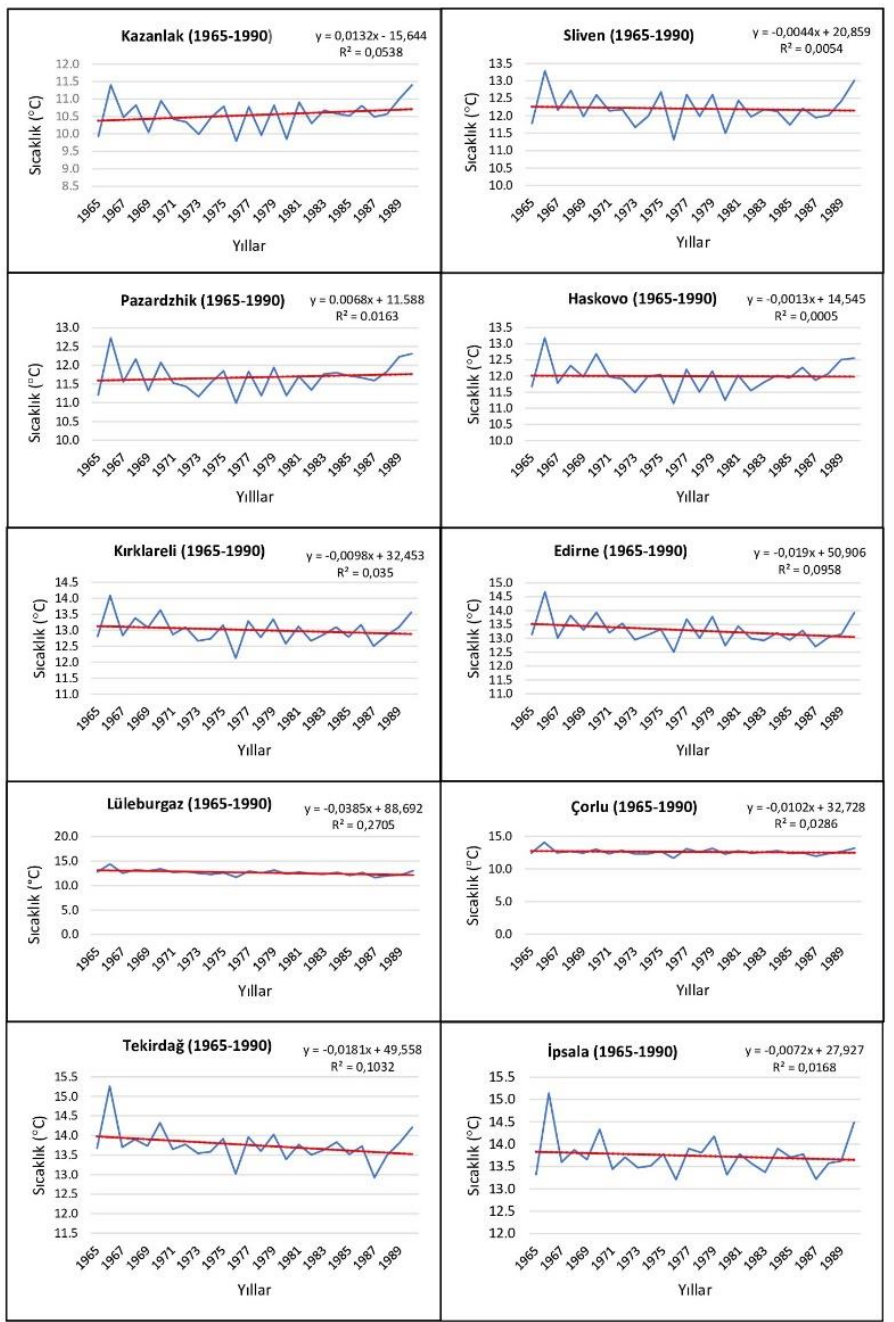

Şekil 2. Meriç Nehri Havzası'nın 1965-1990 Dönemi Sıcaklı Eğilim Grafikleri.

Tablo 4. Meriç Nehri Havzası'nda 1965-1990 Dönemi Yağış Trend Dĕ̌erleri.

\begin{tabular}{|l|c|c|c|}
\hline $\begin{array}{c}\text { İstasyon } \\
\text { Adı }\end{array}$ & $\begin{array}{c}\mathbf{P} \text { (Value) } \\
(\mathbf{\alpha}=\mathbf{0 , 0 5})\end{array}$ & $\begin{array}{c}\text { Kendall's } \\
\text { tau }\end{array}$ & $\begin{array}{c}\text { Sen Trend } \\
\text { Eğimi }\end{array}$ \\
\hline Kazanlak & $\mathbf{0 , 0 0 0}$ & $-0,502$ & $-9,600$ \\
\hline Sliven & $\mathbf{0 , 0 2 2}$ & $-0,323$ & $-6,438$ \\
\hline Pazardzhik & $\mathbf{0 , 0 3 9}$ & $-0,302$ & $-6,579$ \\
\hline Haskovo & $\mathbf{0 , 0 4 3}$ & $-0,286$ & $-6,706$ \\
\hline Kırklareli & 0,201 & $-0,182$ & $-3,492$ \\
\hline Edirne & 0,064 & $-0,262$ & $-4,188$ \\
\hline Lüleburgaz & 0,581 & $-0,054$ & $-0,825$ \\
\hline Çorlu & 0,052 & $-0,274$ & $-4,467$ \\
\hline Tekirdağ & 0,103 & $-0,231$ & $-4,589$ \\
\hline İpsala & $\mathbf{0 , 0 3 1}$ & $-0,305$ & $-4,460$ \\
\hline
\end{tabular}

Meriç Nehri Havzası'ndaki bütün istasyonların 1965-1990 yılları arasındaki yıllık ortalama yağış trendleri negatif yönlüdür (Tablo 4, Tablo 5, Şekil 3, Şekil 4). Bu istasyonlardan Kazanlak, Sliven, Pazardzhik, Haskovo ve İpsala'da anlamlı negatif yönlü trend bulunmuştur. Kırklareli, Edirne, Lüleburgaz, Çorlu ve Tekirdağ'da yıllık yağış trend yönü negatif olmakla birlikte anlamsızdır. Bu verilerden Meriç Nehri Havzası'nın Bulgaristan sınırları içindeki kesiminde yağış değerlerindeki azalmanın anlamlı olduğu, Türkiye sınırları içinde ise sadece İpsala'da anlamlı bir azalma olduğu anlaşılmaktadır.

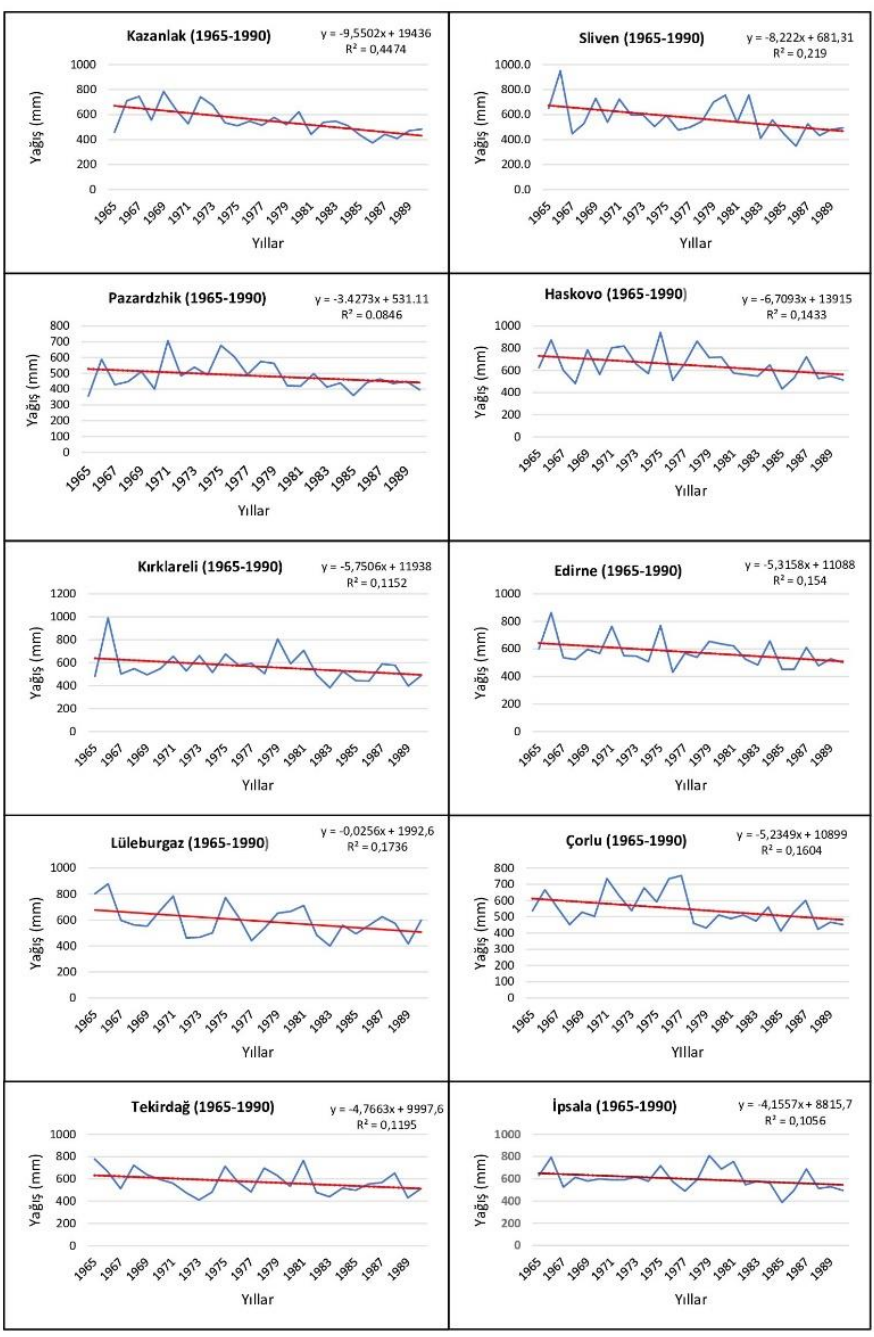

Şekil 3. Meriç Nehri Havzası'nın 1965-1990 Dönemi Yă̆ış Eğilim Grafikleri.

Tablo 5. Meriç Nehri Havzası'nda 1965-1990 Dönemi Yağış Eğilimleri.

\begin{tabular}{|c|c|c|c|}
\hline $\begin{array}{c}\text { İstasyon } \\
\text { Adı }\end{array}$ & $\begin{array}{c}P \text { P (Value) } \\
(\alpha=0,05)\end{array}$ & $\begin{array}{c}\text { Kendall's } \\
\text { tau }\end{array}$ & $\begin{array}{c}\text { Sen Trend } \\
\text { Eğimi }\end{array}$ \\
\hline Kazanlak & & & \\
\hline Sliven & & & \\
\hline Pazardzhik & & & \\
\hline Haskovo & & & \\
\hline Kırklareli & & & \\
\hline Edirne & & & \\
\hline Lüleburgaz & & & 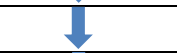 \\
\hline Çorlu & & & 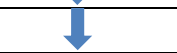 \\
\hline Tekirdağ & & & 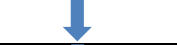 \\
\hline İpsala & & & 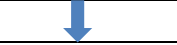 \\
\hline
\end{tabular}




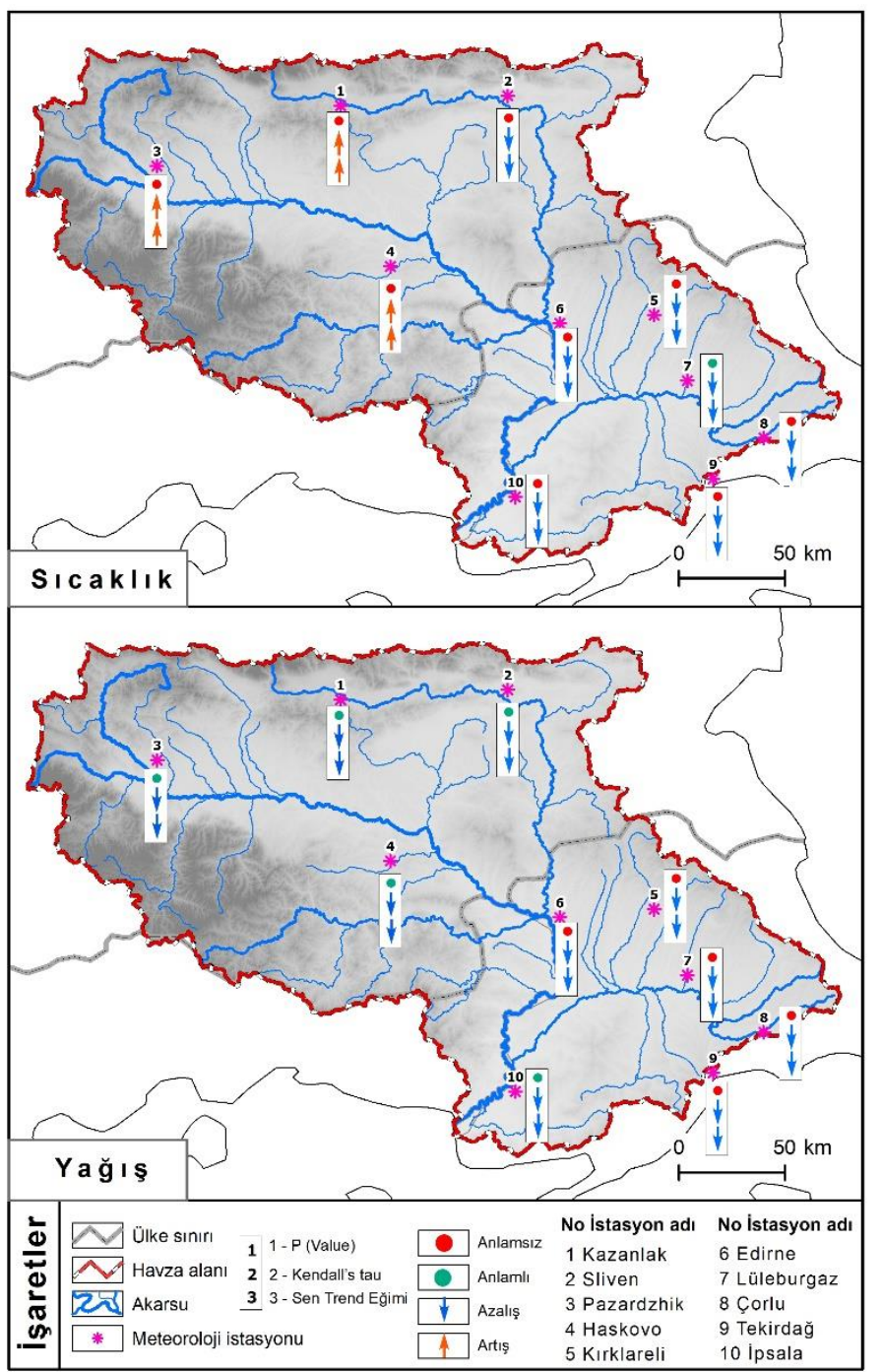

Şekil 4. Meriç Nehri Havzası 'nın 1965-1990 Dönemi Yıllık Ortalama Sıcaklık ve Yă̆ış Eğilim Haritaları.

\subsection{Meriç Havzası'nda 1991-2015 Dönemi Sıcaklık ve Yağış Trend Analizi}

1991-2015 dönemi Meriç Nehri Havzası'nda yıllık ortalama sıcaklık değerlerinin önemli artışlar sergilediği dönemdir. 19651990 döneminde azalma eğiliminde olan yıllık ortalama sicaklık değerleri, bu dönemde bütün istasyonlarda artış eğilimine girmiştir (Tablo 6, Tablo 7, Şekil 5, Şekil 7). Kazanlak, Sliven, Pazardzhik ve Haskovo, Kırklareli, Edirne, Çorlu, Tekirdağ ve İpsala'da anlamlı pozitif eğilimler gözlenmiştir. Lüleburgaz'da da yıllık ortalama sıcaklıkların trend yönü pozitiftir fakat anlamsız bulunmuştur.

Tablo 6. Meriç Nehri Havzası'nda 1991-2015 Dönemi Sıcaklık Trend Değerleri.

\begin{tabular}{|l|c|c|c|}
\hline $\begin{array}{c}\text { İstasyon } \\
\text { Adı }\end{array}$ & $\begin{array}{c}\mathbf{P}(\text { Value }) \\
(\mathbf{\alpha}=\mathbf{0 , 0 5})\end{array}$ & $\begin{array}{c}\text { Kendall's } \\
\text { tau }\end{array}$ & $\begin{array}{c}\text { Sen Trend } \\
\text { Eğimi }\end{array}$ \\
\hline Kazanlak & $\mathbf{0 , 0 0 1}$ & 0,487 & 0,073 \\
\hline Sliven & $\mathbf{0 , 0 0 0}$ & 0,538 & 0,071 \\
\hline Pazardzhik & $\mathbf{0 , 0 0 1}$ & 0,496 & 0,069 \\
\hline Haskovo & $\mathbf{0 , 0 0 2}$ & 0,451 & 0,064 \\
\hline Kırklareli & $\mathbf{0 , 0 0 2}$ & 0,451 & 0,072 \\
\hline Edirne & $<\mathbf{0 , 0 0 0 1}$ & 0,560 & 0,087 \\
\hline Lüleburgaz & 0,315 & 0,147 & 0,037 \\
\hline
\end{tabular}

e-ISSN: 2148-2683

\begin{tabular}{|l|l|l|l|}
\hline Çorlu & $\mathbf{0 , 0 0 1}$ & 0,467 & 0,076 \\
\hline Tekirda $\breve{g}$ & $\mathbf{0 , 0 0 0}$ & 0,533 & 0,081 \\
\hline İpsala & $\mathbf{0 , 0 0 6}$ & 0,393 & 0,045 \\
\hline
\end{tabular}

Tablo 7. Meriç Nehri Havzası 'nda 1991-2015 Dönemi Sıcaklık Eğilimleri.

\begin{tabular}{|c|c|c|c|}
\hline $\begin{array}{c}\text { İstasyon } \\
\text { Adı } \\
\end{array}$ & $\begin{array}{c}\text { P (Value) } \\
(\alpha=0,05)\end{array}$ & $\begin{array}{c}\text { Kendall's } \\
\text { tau }\end{array}$ & $\begin{array}{c}\text { Sen Trend } \\
\text { Eğimi }\end{array}$ \\
\hline Kazanlak & & & 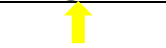 \\
\hline Sliven & & &  \\
\hline Pazardzhil & & & \\
\hline Haskovo & & & renta \\
\hline Kırklareli & & & 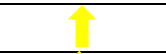 \\
\hline Edirne & & & 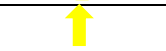 \\
\hline Lüleburgaz & & 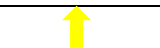 & 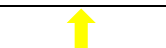 \\
\hline Çorlu & & . & + \\
\hline Tekirdağ & & & 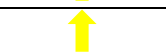 \\
\hline İpsala & & 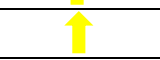 & 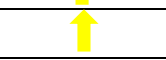 \\
\hline
\end{tabular}

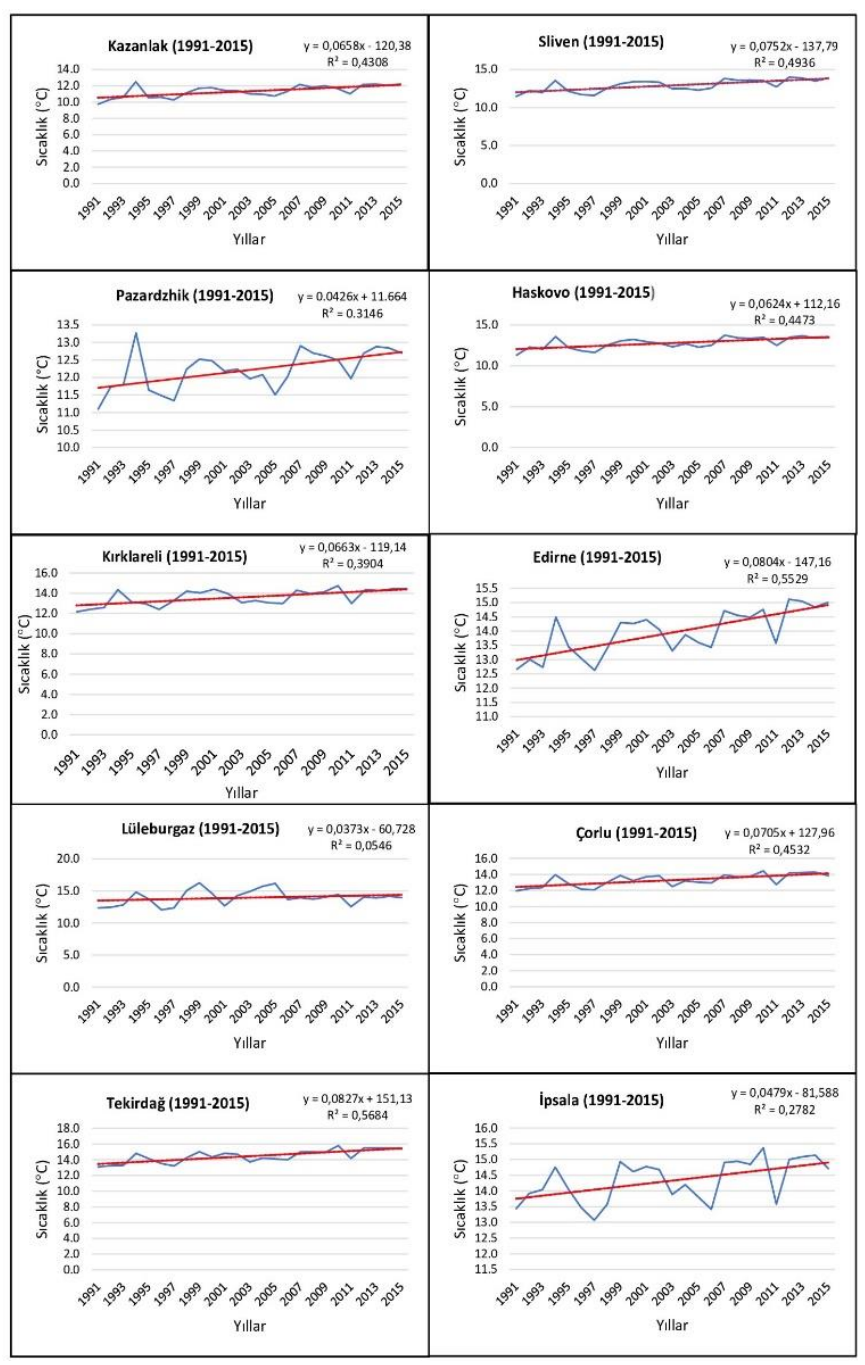

Şekil 5. Meriç Nehri Havzası'nın 1991-2015 Dönemi Sıcaklık Eğilim Grafikleri.

1991-2015 dönemi yıllık yağışlarda Meriç Nehri Havzası'nda sadece Kırklareli istasyonunda anlamlı pozitif yönlü bir trend görülmektedir (Tablo 8, Tablo 9, Şekil 6, Şekil 7). 
Kazanlak, Sliven, Pazardzhik, Haskovo, Edirne, Çorlu, Tekirdağ ve İpsala'da anlamsız pozitif yönlü eğilimler gözlenmektedir. Bu istasyonlardan farklı olarak Lüleburgaz'da trend yönü negatiftir ve anlamsızdır. 1965-1990 döneminde Meriç Nehri Havzası'nın tamamında azalma eğiliminde olan yıllık ortalama yağışlar, 19912015 döneminde artış eğilimine girmiştir.

Tablo 8. Meriç Nehri Havzası 'nda 1991-2015 Dönemi Yağış Trend Değerleri.

\begin{tabular}{|l|c|c|c|}
\hline $\begin{array}{c}\text { İstasyon } \\
\text { Adı }\end{array}$ & $\begin{array}{c}\mathbf{P} \text { (Value) } \\
(\mathbf{a}=\mathbf{0 , 0 5})\end{array}$ & $\begin{array}{c}\text { Kendall's } \\
\text { tau }\end{array}$ & $\begin{array}{c}\text { Sen Trend } \\
\text { Ĕgimi }\end{array}$ \\
\hline Kazanlak* & 0,102 & 0,255 & 6,533 \\
\hline Sliven* & 0,463 & 0,117 & 2,220 \\
\hline Pazardzhik* & 0,357 & 0,131 & 4,720 \\
\hline Haskovo* & 0,236 & 0,186 & 6,700 \\
\hline Kırklareli & $\mathbf{0 , 0 3 8}$ & 0,300 & 10,377 \\
\hline Edirne & 0,065 & 0,267 & 7,706 \\
\hline Lüleburgaz & 0,761 & $-0,07$ & $-2,100$ \\
\hline Çorlu & 0,834 & 0,033 & 1,112 \\
\hline Tekirdağ & 0,272 & 0,160 & 4,442 \\
\hline İpsala & 0,072 & 0,260 & 8,051 \\
\hline
\end{tabular}

(*1991-2012)

Tablo 9. Meriç Nehri Havzası 'nda 1991-2015 Dönemi Yă̆ış Ĕ̈ilimleri.

\begin{tabular}{|c|c|c|c|}
\hline $\begin{array}{c}\text { İstasyon } \\
\text { Adı }\end{array}$ & $\begin{array}{c}\text { P (Value) } \\
(\alpha=0,05)\end{array}$ & $\begin{array}{c}\text { Kendall's } \\
\text { tau }\end{array}$ & $\begin{array}{c}\text { Sen } \\
\text { Trend } \\
\text { Eğimi }\end{array}$ \\
\hline Kazanlak* & & & 1 \\
\hline Sliven* & & & {[} \\
\hline Pazardzhik* & & & 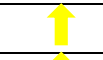 \\
\hline Haskovo* & & & t \\
\hline Kırklareli & & & \\
\hline Edirne & & & \\
\hline Lüleburgaz & & & 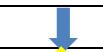 \\
\hline Çorlu & & & \\
\hline Tekirdağ & & & 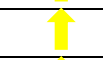 \\
\hline İpsala & & & 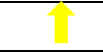 \\
\hline
\end{tabular}

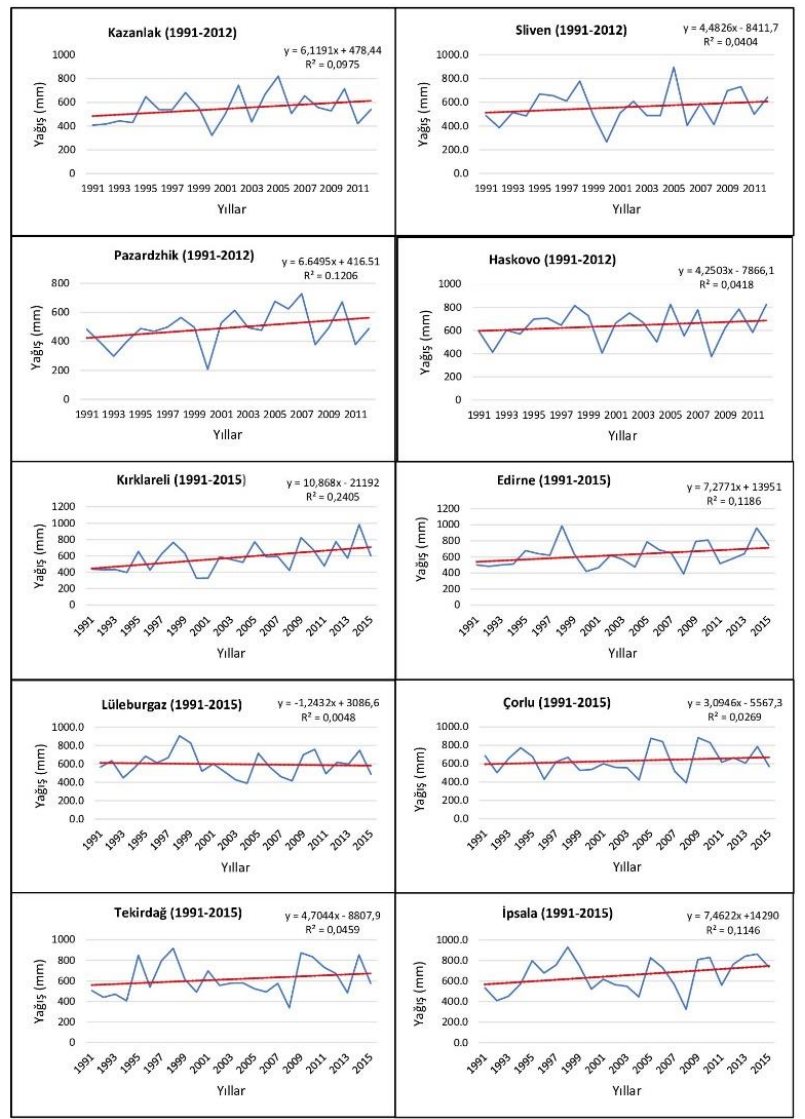

Şekil 6. Meriç Nehri Havzası'nın 1991-2015 Dönemi Yağış Ĕ̈ilim Grafikleri.



Şekil 7. Meriç Nehri Havzası'nın 1991-2015 Dönemi Yıllık Ortalama Sicaklık ve Yağış Eğilim Haritalart. 


\subsection{Meriç Nehri Havzası'nda 1965-2015 Dönemi Sıcaklık ve Yağıș Trend Analizi}

Meriç Nehri Havzası'nda 1965-2015 dönemi sıcaklık ortalamaları incelendiğinde Kazanlak, Sliven, Pazardzhik, Haskovo, Kırklareli, Edirne, Lüleburgaz, Çorlu, Tekirdağ ve İpsala'da sıcaklık trendleri anlamlı ve pozitif yönlüdür (Tablo 10, Tablo 11, Şekil 8, Şekil 10). Başka bir deyişle Meriç Nehri Havzası'nda 1965 yılından bu yana geçen 50 yıllık sürede sıcaklıklar artmış ve bu artış eğilimi sürmektedir.

Diğer taraftan 1965-1990 döneminde genel anlamda azalma trendinde olan yıllık ortalama sicaklıklar 1991-2015 ve 19652015 döneminde artış trendine girmiştir.

Tablo 10. Meriç Nehri Havzası'nda 1965-2015 Dönemi Sıcaklık Trend Değerleri.

\begin{tabular}{|l|c|c|c|}
\hline $\begin{array}{c}\text { İstasyon } \\
\text { Adı }\end{array}$ & $\begin{array}{c}\mathbf{P}(\text { Value) } \\
(\boldsymbol{\alpha}=\mathbf{0 , 0 5})\end{array}$ & $\begin{array}{c}\text { Kendall's } \\
\text { tau }\end{array}$ & $\begin{array}{c}\text { Sen } \\
\text { Trend } \\
\text { Ĕgimi }\end{array}$ \\
\hline Kazanlak & $<\mathbf{0 , 0 0 0 1}$ & 0,475 & 0,034 \\
\hline Sliven & $<\mathbf{0 , 0 0 0 1}$ & 0,383 & 0,028 \\
\hline Pazardzhik & $<\mathbf{0 , 0 0 0 1}$ & 0,418 & 0,021 \\
\hline Haskovo & $<\mathbf{0 , 0 0 0 1}$ & 0,477 & 0,033 \\
\hline Kırklareli & $\mathbf{0 , 0 0 2}$ & 0,305 & 0,022 \\
\hline Edirne & $\mathbf{0 , 0 0 1}$ & 0,333 & 0,028 \\
\hline Lüleburgaz & $\mathbf{0 , 0 0 8}$ & 0,256 & 0,030 \\
\hline Çorlu & $\mathbf{0 , 0 0 0}$ & 0,350 & 0,028 \\
\hline Tekirda $\breve{g}$ & $\mathbf{0 , 0 0 0}$ & 0,353 & 0,028 \\
\hline İpsala & $\mathbf{0 , 0 0 0}$ & 0,348 & 0,023 \\
\hline
\end{tabular}

Tablo 11. Meriç Nehri Havzası'nda 1965-2015 Dönemi Sıcaklık Ĕ̈ilimleri.

\begin{tabular}{|c|c|c|c|}
\hline $\begin{array}{c}\text { İstasyon } \\
\text { Adı } \\
\end{array}$ & $\begin{array}{c}\text { P (Value) } \\
(\alpha=0,05)\end{array}$ & $\begin{array}{c}\text { Kendall's } \\
\text { tau }\end{array}$ & $\begin{array}{c}\text { Sen Trend } \\
\text { Eğimi }\end{array}$ \\
\hline Kazanlak & & s & \\
\hline Sliven & & 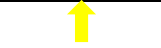 & \\
\hline Pazardzhik & & 1 & \\
\hline Haskovo & & 1 & \\
\hline Kırklareli & & 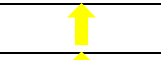 & \\
\hline Edirne & & 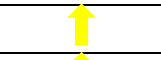 & 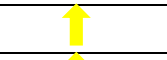 \\
\hline Lüleburgaz & & 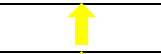 & 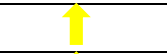 \\
\hline Çorlu & & 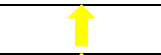 & . \\
\hline Tekirdağ & &  & 1 \\
\hline İpsala & & + & + \\
\hline
\end{tabular}

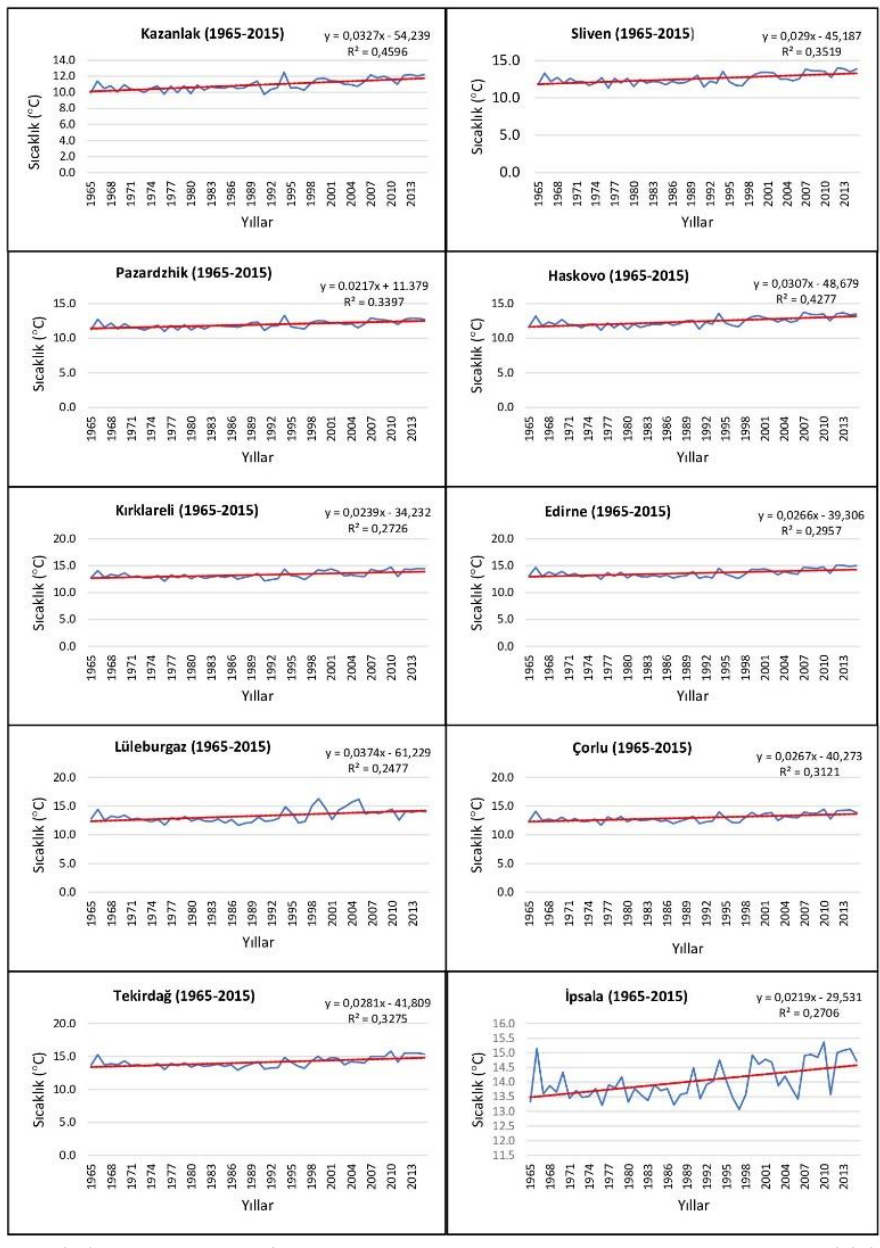

Şekil 8. Meriç Nehri Havzası'nın 1965-2015 Dönemi Sıcaklık Eğilim Grafikleri.

1965-2015 yılları arası dönemde Meriç Nehri Havzası'na ait yağış trendleri hiç bir istasyonda istatistiksel olarak anlamlı değildir (Tablo 12, Tablo 13, Şekil 9, Şekil 10). Kazanlak, Sliven, Pazardzhik, Haskovo, ve Lüleburgaz meteoroloji istasyonlarının yıllık yağış ortalamalarında negatif yönlü bir eğilim Kırklareli, Edirne, Çorlu, Tekirdağ ve İpsala'da pozitif yönlü bir eğilim vardir.

Tablo 12. Meriç Nehri Havzası'nda 1965-2015 Dönemi Yă̆ı̧ Trend Değerleri.

\begin{tabular}{|l|c|c|c|}
\hline $\begin{array}{c}\text { İstasyon } \\
\text { Adı }\end{array}$ & $\begin{array}{c}\mathbf{P}(\text { Value }) \\
(\boldsymbol{\alpha}=\mathbf{0 , 0 5})\end{array}$ & $\begin{array}{c}\text { Kendall's } \\
\text { tau }\end{array}$ & $\begin{array}{c}\text { Sen Trend } \\
\text { Eğimi }\end{array}$ \\
\hline Kazanlak* & 0,315 & $-0,101$ & $-1,009$ \\
\hline Sliven* $^{*}$ & 0,369 & $-0,090$ & $-1,077$ \\
\hline Pazardzhik* $^{*}$ & 0,593 & $-0,086$ & $-0,643$ \\
\hline Haskovo* $^{*}$ & 0,838 & $-0,021$ & $-0,398$ \\
\hline Kırklareli & 0,685 & 0,040 & 0,654 \\
\hline Edirne & 0,389 & 0,084 & 1,108 \\
\hline Lüleburgaz & 0,113 & $-0,225$ & $-0,223$ \\
\hline Çorlu & 0,188 & 0,128 & 1,750 \\
\hline Tekirdağ & 0,564 & 0,056 & 0,558 \\
\hline İpsala & 0,346 & 0,092 & 1,414 \\
\hline
\end{tabular}

(*1965-2012) 
Tablo 13. Meriç Nehri Havzası'nda 1965-2015 Dönemi Yă̆ıS Ĕ̈ilimleri.

\begin{tabular}{|l|c|c|c|}
\hline $\begin{array}{c}\text { İstasyon } \\
\text { Adı }\end{array}$ & $\begin{array}{c}\mathbf{P} \text { (Value) } \\
(\mathbf{a}=\mathbf{0 , 0 5})\end{array}$ & $\begin{array}{c}\text { Kendall's } \\
\text { tau }\end{array}$ & $\begin{array}{c}\text { Sen Trend } \\
\text { Eğimi }\end{array}$ \\
\hline Kazanlak* & - & & \\
\hline Sliven* & & & \\
\hline Pazardzhik* & & & \\
\hline Haskovo* & & & \\
\hline Kırklareli & & & \\
\hline Edirne & & & \\
\hline Lüleburgaz & & & \\
\hline Çorlu & & & \\
\hline Tekirdağ & & & \\
\hline İpsala & & & \\
Anlamsız & & \\
\hline
\end{tabular}

\begin{tabular}{|c|c|}
\hline 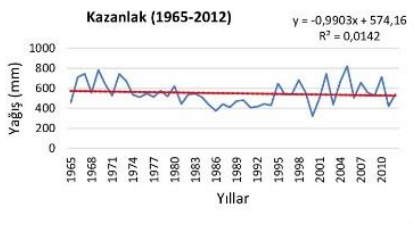 & 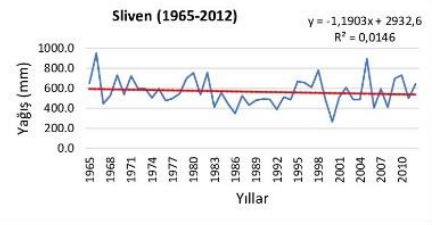 \\
\hline 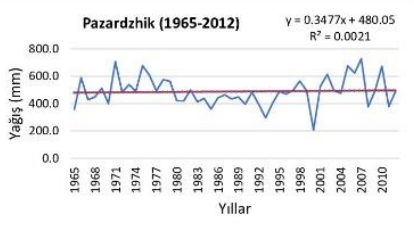 & 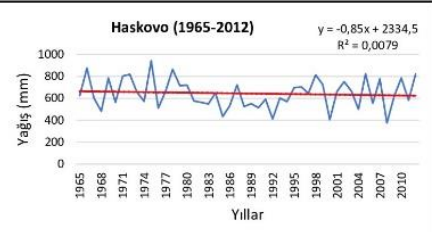 \\
\hline 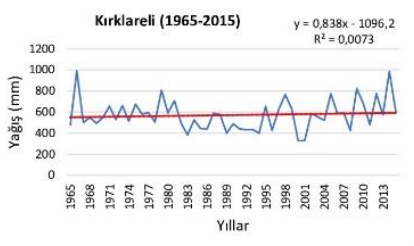 & 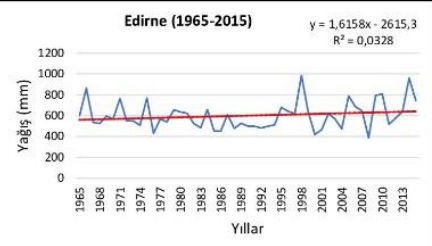 \\
\hline 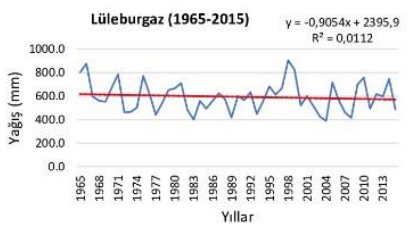 & 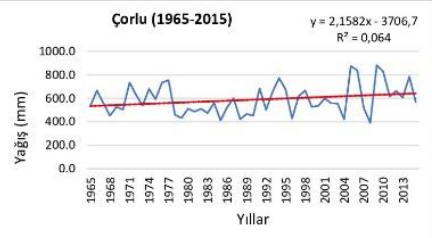 \\
\hline 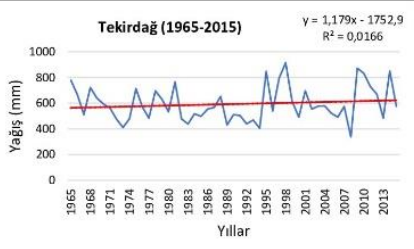 & 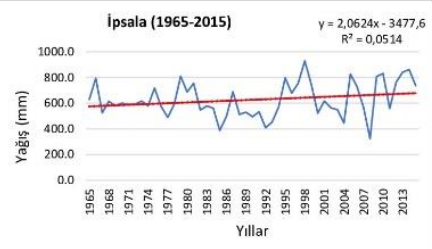 \\
\hline
\end{tabular}

Şekil 9. Meriç Nehri Havzası'nın 1965-2015 Dönemi Yağış Ĕgilim Grafikleri.

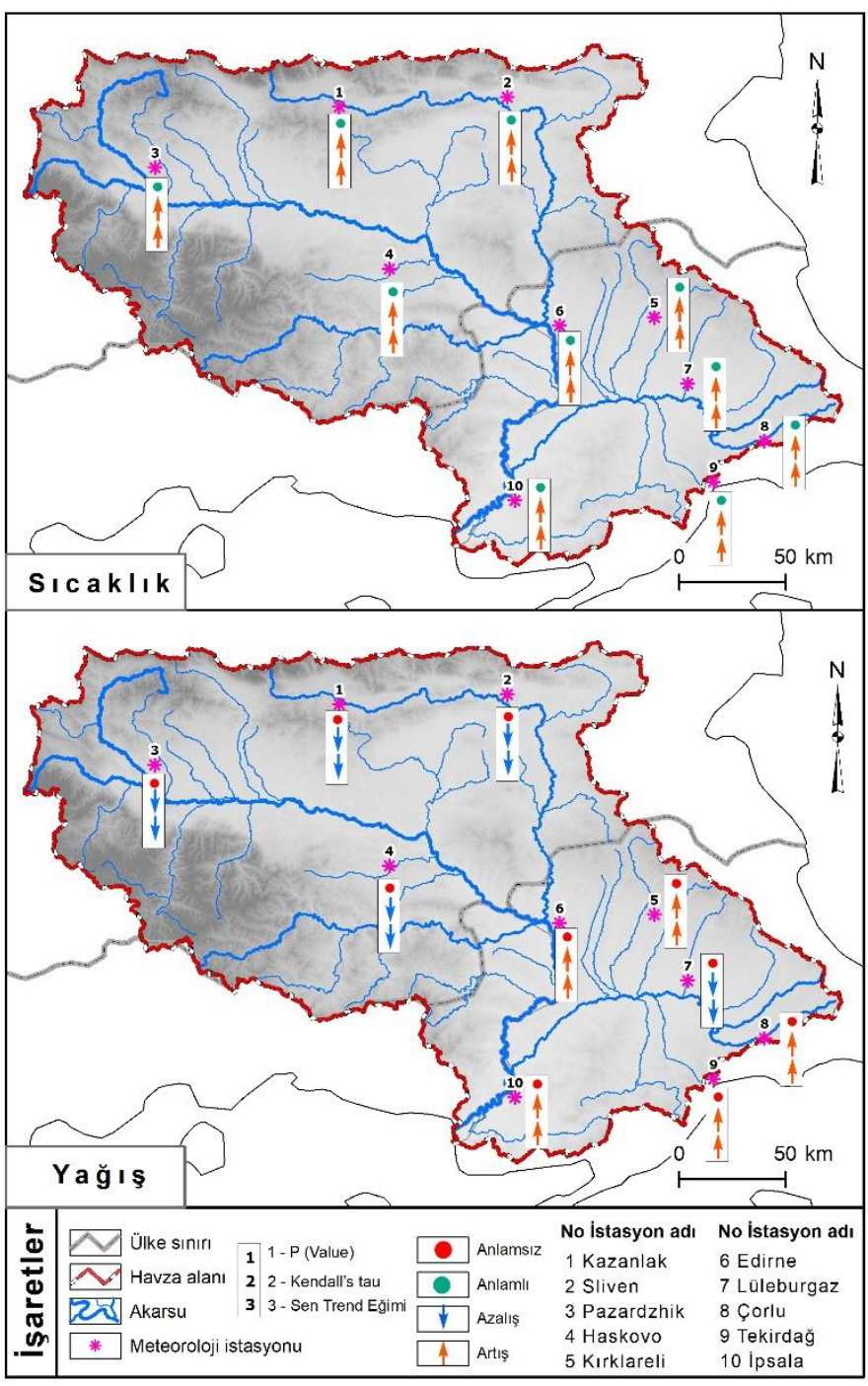

Şekil 10. Meriç Nehri Havzası'nın 1965-2015 Dönemi Yıllık Ortalama Slcaklık ve Yağış Eğilim Haritaları.

\section{Sonuç}

Meriç Nehri Havzası'nda yıllık sıcaklık ortalamaları 19651990 döneminde bütün istasyonlarda azalmakla birlikte sadece Lüleburgaz'da istatistiksel olarak anlamlı azalış göstermektedir. $\mathrm{Bu}$ dönemin yıllık ortalama yağışlarında trend yönü azalma yönündedir. Havza alanının Bulgaristan'da kalan kesiminin tamamında ve İpsala'da yıllık yağış azalma eğilimi istatistiki olarak anlamlıdir.

Meriç Nehri Havzası'nın bu çalışmada ortaya konulan 19651990 dönemi yıllık ortalama sıcaklık ve yağış trend yönleri Kadıŏlu (1997), Türkeş (1996), Knight ve Staneva (1996) ve Partal'ın (2002) bulgulariyla uyumludur.

Y1llık ortalama sicakliklar 1991-2015 ve 1965-2015 dönemlerinde Meriç Nehri Havzası genelinde anlamlı pozitif eğilimler göstermektedir. Yıllık ortalama yağışlar 1965-1990 döneminde bütün istasyonlarda istatistiksel olarak anlamlı olmasa da azalış yönünde bir trend göstermektedir. 1991-2015 döneminde yağışlar Kırklareli’nde istatistiksel olarak anlamlı olmak üzere genel olarak artış yönündedir. Y1llık ortalama yağışlarda 1965-2015 dönemi yani bütün rasat dönemi geneli esas alındığında Meriç Nehri’nin Bulgaristan'da kalan kesiminde azalma, Türkiye sınırları içinde kalan kesiminde Lüleburgaz hariç olmak üzere artış yönünde bir trend görülmektedir. Ancak havza 
genelinde yer alan hiçbir istasyonun trend yönleri istatistiksel olarak anlamlı değildir. Bu trend sonuçlarının Gönençgil (2012), Meteoroloji Genel Müdürlüğü (2014) ve Hanedar vd. (2019)'nin yaptıkları çalışmalar ile uyumlu olduğu söylenebilir.

Meriç Nehri Havzası'ndaki bütün istasyonların sıcaklık değerlerinde 1990-2015 döneminde ortaya çıkan pozitif yönlü anlamlı trendler küresel iklim değişikliğinin sıcaklık ve yağış parametreleri üzerindeki etkisinin son yıllarda çok daha hissedilmeye başlandığını göstermesi açısından oldukça manalıdır. Meriç Nehri sınır aşan bir akarsu olduğundan havza alanının Bulgaristan'da kalan kesimlerinde yağış miktarının artış ya da azalış yönünde seyir izlemesi hiç şüphesiz Aşağı Meriç Havzası'nda akım rejim özelliklerinin değişmesine ve dolayısıyla taşkınlara veya su sıkıntısı çekilmesine neden olabilecektir. Zira Turoğlu ve Uludağ (2013), Meriç Nehri Havzası'nın Türkiye'deki bölümünde taşkın, su yetersizliği, su kalitesi vb. pek çok problemin giderek arttığını özellikle vurgulamışlardır.

Meriç Nehri'nin Bulgaristan tarafında yağış miktarı ve rejiminde görülen değişmeler, erozyon alanlarından taşınan toprak miktarının artmasına ve bu durumdan Türkiye sınırları içindeki arazilerin de olumsuz etkilenmesine yol açmaktadır. Bulgaristan arazisinde $\% 78$ oranında düşük erozyon, \%6,07 şiddetli erozyon, \%5,26 hafif erozyon, \%5,09 yüksek erozyon ve $\% 4,89$ orta derecede erozyon belirlenmiştir (Özşahin vd., 2019). Havza alanındaki tarım alanlarında ise RUSLE yöntemine göre 1990-2015 yılları arasında toprak kaybı oranında dikkate değer artış tespit edilmiştir (Özşahin vd., 2018). Türkiye sınırları içinde Meriç Nehri'nin erozyon ve taşkın zararlarını azaltmak ve verimli tarım alanlarının zarar görmemesi için ülkeler arası işbirliğinde Türkiye kadar diğer ülkelerde gerekli hassasiyeti göstermelidir.

Meriç Nehri Havzası'nın iklim özelliklerinde değişikliklerin yaşanması havza alanında kuraklık, toprak erozyonu, arazi degradasyonu, su kıtlığı veya taşkın riskinin artması, ekolojik dengede bozulmalar, tarımsal verimin düşmesi, ürün çeşitliliğinin azalması, büyükbaş ve küçükbaş hayvancılık faaliyetlerinin olumsuz etkilenmesi gibi sorunlara yol açacaktır. Bu sorunların büyümeden çözülmesi için havza alanı ile ilgili planlamalarda ortalama sıcaklık ve yağış trendlerindeki değişikliklerin sonuçları göz önünde bulundurulmalıdır.

\section{Teşekkür}

Kazanlık, Sliven, Pazardzhik ve Haskovo meteoroloji istasyonlarına ait sicaklık ve yağış verilerinin temininde yardımlarını esirgemeyen Peter NOJAROV'a teşekkür ederim.

\section{Kaynakça}

Ardel, A., Kurter, A. \& Dönmez, Y. (1965). Klimatoloji Tatbikatı. İstanbul: İstanbul Üniversitesi Yayın No:1123, Coğrafya Enstitüsü Yayın No: 40.

Atalay, İ. (2013). Uygulamalı Klimatoloji (2. Baskı). İzmir: Meta Basım Matbaacılik Hizmetleri.

Bayer Altın, T. \& Barak B. (2012). Seyhan Havzası'nda 19702009 yılları arasında yağış ve sıcaklık değerlerindeki değişmeler ve eğilimler. Türk Coğrafya Dergisi, 58, 21-34.

Büyükyıldız, M. \& Berktay, A. (2004). Parametrik olmayan testler kullanılarak Sakarya havzası yağışlarının trend analizi. Selçuk Üniversitesi Mühendislik-Mimarlık Fakültesi Dergisi, 19(2), 23-38.
Coşkun, S. (2020a). Van Gölü kapalı Havzası'nda yağışların trend analizi. Mühendislik Bilimleri ve Tasarım Dergisi, 8(2), 521532.

Coşkun, S. (2020b). Aras-Kura kapalı Havzası'nın ortalama sıcaklık, yağış ve akım verilerinin trend analizi (Türkiye). Firat Üniversitesi Sosyal Bilimler Dergisi, 30(2), 29-42.

Coşkun, S. (2020c). Akarçay kapalı Havzası'nın ortalama sıcaklık ve yağış verilerinin eğilim analizi (Afyonkarahisar-Türkiye). Jass Studies-The Journal of Academic Social Science Studies, 81, 533-547. http://dx.doi.org/10.29228/JASSS.44156

Çalışkan, O. (2016). Klimatolojik araştırmalar. Nurettin Özgen, Sabri Karadoğan (Ed). Fiziki coğrafyada araştırma yöntemleri ve teknikleri içinde (ss. 247-290). Ankara: PEGEM Akademi.

Çeribaşı, G. \& Doğan, E. (2015). Trend analizi yöntemi kullanılarak Batı ve Doğu Karadeniz ile Sakarya havzası akım miktarlarının değerlendirilmesi. SDU International Technologic Science, 7(2), 1-12.

Demir, İ., Kılıç, G., Coşkun, M. \& Sümer, U. M. (2008). Türkiye'de maksimum, minimum ve ortalama hava sıcaklıkları ile yağış dizilerinde gözlenen değişiklikler ve eğilimler. TMMOB İklim Değişimi Sempozyumu (13-14 Mart 2008) Bildiriler Kitabı içinde (ss. 69-84). Ankara: TMMOB adına TMMOB Meteoroloji Mühendisleri Odası,

Erkal, T. \& Topgül, İ. (2015). Meriç Nehri'nin son 15 yıllık taşkınları ve korunma projeleri. TÜCAUM VIII. Coğrafya Sempozyuтu (23-24 Ekim 2014) Bildiriler Kitabı içinde (ss.165-174). Ankara: Ankara Dil ve Tarih-Coğrafya Fakültesi.

Erkal, T. \& Topgül, İ. (2020). Aşağı Meriç Nehri akımlarının mevsimsel ve yıllık değişiminin taşkınlar üzerine etkisi. Türk Coğrafya Dergisi, 74, 33-38. DOI: 10.17211/tcd.645865.

Gocic, M. \& Slavisa, T. (2013). Analysis of changes in meteorological variables using Mann-Kendall and Sen's slope estimator statistical tests in Serbia. Global and Planetary Change, 100, 172-182. http://dx.doi.org/10.1016/j.gloplacha.2012.10.014.

Gönençgil, B. (2012). Climate characteristics of Thrace and observed temperature - precipitation trends. The Balkans at a Crossroads: Evaluating Past, Reading Present, Imagining Future (11-14 October 2012), Tirana. Bekir Çınar (Ed). Conference Proceeding Book. Vol.2 içinde (ss. 80-95). 24.01.2021 tarihinde http://cdn.istanbul.edu.tr/FileHandler2.ashx?f=ibac-2012albania-volume-ii-1.pdf adresinden erişildi.

Hanedar, A., Çağlar, F., Görgün, E., Konukçu, F., Altürk, B. \& Albut, S. (2019). TR21 Bölgesi iklim değerlendirmesi: Mevcut durum ve projeksiyonlar. Konukçu F., Albut S., Altürk B. (Ed). TR 21 Trakya bölgesinde iklim değişikliğinin etkileri ve uyum stratejileri içinde (s.1-22), Tekirdağ: Tekirdağ Namık Kemal Üniversitesi Toprak Ofset.

Kadıoğlu, M. (1997). Trends in surface air temperature data over Turkey. International Journal Of Climatology, 17, 511-520.

Kadığlu, M. (2019). Bildiğiniz havaların sonu küresel iklim değişimi ve Türkiye. (Gözden geçirilmiş ve güncellenmiş basım). İstanbul: Sia Kitap.

Karabulut, M. \& Cosun, F. (2009). Kahramanmaraş ilinde yağışların trend analizi. Coğrafi Bilimler Dergisi, 7 (1), 65 83.

Kızılelma, Y., Çelik, M. A. \& Karabulut, M. (2015). İç Anadolu Bölgesinde sicaklık ve yağışların trend analizi. Türk Cografya Dergisi, $\quad 64$, 1-10. https://doi.org/10.17211/tcd.90494. 
Knight, C. G. \& Staneva, M. (1996). The water resources of Bulgaria: an overview. GeoJournal, 40(4), 347362. doi:10.1007/bf00183411

Nojarov, P. (2017). Genetic climatic regionalization of the Balkan peninsula using cluster analysis. Journal of Geographical Sciences, 27(1), 43-61. DOI: 10.1007/s11442-017-1363-y.

Ölgen, M. K. (2010). Türkiye'de yıllık ve mevsimsel yağış değişkenliğinin alansal dağılımı. Ege Coğrafya Dergisi, 19(1), 85-95.

Özşahin, E. \& Eroğlu, İ. (2019). Frog hunting in Edirne province (Thrace, Turkey). Recep Efe, Irina Koleva, Münir Öztürk, Ramiz Arabac1 (Ed.), Recent Advances in Social Sciences içinde (ss. 575-584). Cambridge Scholars Publishing.

Özşahin E., Duru Ü. \& Eroğlu İ. (2018). Land use and land cover changes (LULCC), a key to understand soil erosion intensities in the Maritsa Basin. Water,10, 1-15.

Özşahin, E., Eroğlu, İ. \& Ocak, A. (2019). Soil erosion in Bulgaria. Dimitar Kirilov Dimıtrov, Dimitar N1kolosk1 Rasim Yılmaz (Ed.) XI. IBANESS Congress Series-Tekirdağ / TURKEY. (09-10 Mart 2019) Proceedings Book içinde (ss. 1234-1237).

Özşahin, E., Eroğlu, İ. \& Özdeş, M. (2020). Yerşekilleri ve AKAÖ (arazi kullanımı/arazi örtüsü) arasındaki ilişkinin incelenmesi: Hisarlıdă̆ ve yakın çevresi örneği (Enez/Edirne). Salih Birinci, Çağlar Kıvanç Kaymaz, Yusuf Kızılkan (Ed). Coğrafi perspektifle dă̆ ve dă̆lık alanlar (sürdürülebilirlik-yönetim-örnek alan incelemeleri içinde (ss. 73-100). İstanbul: Kriter Yayınevi.

Partal, T. (2002). Türkiye yăğlş verilerinin trend analizi. (Yayımlanmamış Doktora Tezi). İstanbul Teknik Üniversitesi, Fen Bilimleri Enstitüsü, İnşaat Mühendisliği Anabilim Dalı Hidrolik ve Su Kaynakları Mühendisliği Program1, İstanbul.

Partal, T. \& Kahya, E. (2006). Trend analysis in Turkish precipitation data. Hydrological Processes. 20, 2011-2026. Do1: 10.1002/Hyp.5993.

Polat, P.\& Sunkar, M. (2017). Rize'nin iklim özellikleri ve Rize çevresinde uzun dönem sicaklık ve yağış verilerinin trend analizleri. Firat Üniversitesi Sosyal Bilimler Dergisi, 27(1), $1-23$.

Roboaa, E. M. \& Al-Barazanji, Z. (2015). Mann-Kendall trend analysis of surface air temperatures and rainfall in Iraq. Quarterly Journal of the Hungarian Meteorological Service, 119(4), 493-514.

Saplıŏlu, K. \& Çoban, E. (2013). Karadeniz Bölgesi yă̆ı̧ serilerinin trend analizi. VII. Ulusal Hidroloji Kongresi (2627 Eylül 2013), (ss. 500-512). Isparta: Süleyman Demirel Üniversitesi.

Sütgibi, S. (2015). Büyük Menderes Havzası'nın sıcaklık, yağış ve akım değerlerindeki değişimler ve eğilimler. Marmara Coğrafya Dergisi, 31, 398-414. DOI: 10.14781/mcd.36029.

Şenocak, S. \& Emek, M. F. (2019).Trend analizi yöntemleri kullanılarak Doğu Anadolu Bölgesi aylık yağış miktarlarının değerlendirilmesi, Avrupa Bilim ve Teknoloji Dergisi, 17, 807-822.

T.C. Orman ve Su İşleri Bakanlığı Meteoroloji Genel Müdürlüğü (2014). İklim projeksiyonlarına göre akarsu havzalarında sıcaklık ve yağış değerlendirmesi. Ankara: Araştırma Dairesi Başkanlığı Klimatoloji Şube Müdürlüğü. 09.02.2021 tarihinde

https://www.mgm.gov.tr/FILES/iklim/yayinlar/2014/iklimProjeksiyonlari-ve-Havzalar-2014.pdf adresinden erişildi.
T.C. Orman ve Su İşleri Bakanlığı Meteoroloji Genel Müdürlüğü (2017). Çorlu, Edirne, İpsala, Kırklareli, Lüleburgaz ve Tekirdağ meteoroloji istasyonlarının sıcaklık ve yağış verileri.

Turoğlu, H. \& Uludağ, M. (2013). Possible hydrographic effects of climate change on lower part of transboundary Meriç rıver basin (Turkey). Trakya University Journal of Natural Sciences, 14(2), 77-85.

Türkeş, M. (1996). Spatial and temporal analysis of annual rainfall variations in Turkey. International Journal of Climatology, 16, 1057-1076.

Türkeş, M. (2012). Türkiye'de gözlenen ve öngörülen iklim değişikliği, kuraklık ve çölleşme. Ankara Üniversitesi Çevrebilimleri Dergisi, 4(2), 1-32.

Türkeş, M., Koç, T. \& Sarış, F. (2007). Türkiye'nin yağış toplamı ve yoğunluğu dizilerindeki değişikliklerin ve eğilimlerin zamansal ve alansal çözümlemesi. Coğrafi Bilimler Dergisi, $5(1), 57-73$

Yıldız, D. (2011). Meriç Nehri havzası su yönetiminde uluslararası işbirliği zorunluluğu. Ankara: ORSAM Rapor No: 44. ORSAM Su Araştırmaları Programı Rapor No: 4. 24 Ocak 2021 tarihinde https://www.orsam.org.tr/tr/mericNehri-havzasi-su-yonetimi-nde-uluslararasi-isbirligizorunlulugu/ adresinden erişildi.

Yu, Y. S., Zou, S. \& Whittemore, D. (1993) Non-parametric trend analysis of water quality data of rivers in Kansas, Journal of Hydrology, 150, 61-80.

https://www.xlstat.com/en/download/xlstat (Erişim tarihi: 10.10.2020). 